\title{
Thyroid Stimulating Hormone Receptor Antibody Measurement
}

National Cancer Institute

\section{Source}

National Cancer Institute. Thyroid Stimulating Hormone Receptor Antibody

Measurement. NCI Thesaurus. Code C122158.

The determination of the amount of thyroid stimulating hormone receptor antibody present in a sample. 